\title{
Invited review: Opportunities for genetic improvement of metabolic diseases
}

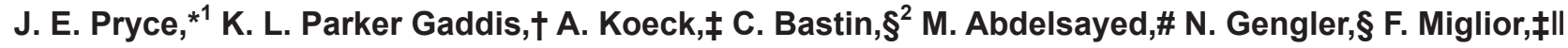 \\ B. Heringstad, C. Egger-Danner, ${ }^{* *}$ K. F. Stock,†† A. J. Bradley, $¥ \S \S$ and J. B. Cole\#\# \\ *Department of Economic Developments, Jobs, Transport and Resources and La Trobe University, Agribio, 5 Ring Road, Bundoora, VIC 3083 , \\ Australia \\ †Department of Animal Sciences, University of Florida, Gainesville 32611 \\ ¥Centre for Genetic Improvement of Livestock, University of Guelph, Guelph, ON, N1G 2W1, Canada \\ §Agriculture, Bio-engineering and Chemistry Department, Gembloux Agro-Bio Tech, University of Liège, B-5030 Gembloux, Belgium \\ \#Holstein Australia, 24-36 Camberwell Road, Hawthorn East, Victoria, 3122, Australia \\ IICanadian Dairy Network, Guelph, ON, N1K 1E5, Canada \\ TDepartment of Animal and Aquacultural Sciences, Norwegian University of Life Sciences, PO Box 5003, NO-1432 Ås, Norway \\ **ZuchtData EDV-Dienstleistungen GmbH, Dresdner Str. 89/19, A-1200 Vienna, Austria \\ ††Vereinigte Informationssysteme Tierhaltung w.V. (vit), Heinrich-Schroeder-Weg 1, D-27283 Verden, Germany \\ $\ddagger \ddagger$ University of Nottingham, School of Veterinary Medicine and Science, Sutton Bonington Campus, Sutton Bonington, Leicestershire, LE12 5RD, \\ United Kingdom, and \\ $\S \S$ Quality Milk Management Services Ltd., Cedar Barn, Easton Hill, Easton, Wells, Somerset, BA5 1EY, United Kingdom \\ \#\#Animal Genomics and Improvement Laboratory, Agricultural Research Service, USDA, Beltsville, MD 20705
}

\section{ABSTRACT}

Metabolic disorders are disturbances to one or more of the metabolic processes in dairy cattle. Dysfunction of any of these processes is associated with the manifestation of metabolic diseases or disorders. In this review, data recording, incidences, genetic parameters, predictors, and status of genetic evaluations were examined for (1) ketosis, (2) displaced abomasum, (3) milk fever, and (4) tetany, as these are the most prevalent metabolic diseases where published genetic parameters are available. The reported incidences of clinical cases of metabolic disorders are generally low (less than $10 \%$ of cows are recorded as having a metabolic disease per herd per year or parity/lactation). Heritability estimates are also low and are typically less than 5\%. Genetic correlations between metabolic traits are mainly positive, indicating that selection to improve one of these diseases is likely to have a positive effect on the others. Furthermore, there may also be opportunities to select for general disease resistance in terms of metabolic stability. Although there is inconsistency in published genetic correlation estimates between milk yield and metabolic traits, selection for milk yield may be expected to lead to a deterioration in metabolic disorders. Under-recording and difficulty in

Received January 4, 2016

Accepted May 26, 2016.

${ }^{1}$ Corresponding author: jennie.pryce@ecodev.vic.gov.au

${ }^{2}$ Current address: Walloon Breeding Association (awe), B-5530 Ciney, Belgium. diagnosing subclinical cases are among the reasons why interest is growing in using easily measurable predictors of metabolic diseases, either recorded on-farm by using sensors and milk tests or off-farm using data collected from routine milk recording. Some countries have already initiated genetic evaluations of metabolic disease traits and currently most of these use clinical observations of disease. However, there are opportunities to use clinical diseases in addition to predictor traits and genomic information to strengthen genetic evaluations for metabolic health in the future.

Key words: metabolic disease, ketosis, displaced abomasum, milk fever

\section{INTRODUCTION}

In dairy cattle management, data recording, and genetic evaluation, interest has been growing in reducing the manifestation of dairy production diseases to improve animal welfare, production efficiency, and farm profitability. The image of the dairy industry is also of great importance, as consumer awareness and interest in animal welfare and consequent societal effects have become more prominent (Boichard and Brochard, 2012). Common dairy cattle health disorders, such as mastitis and lameness-causing claw diseases, have received a large amount of attention, as the relative economic effect of these diseases is substantial (e.g., Kelton et al., 1998; Cha et al., 2010, 2011). In comparison, the literature pertaining to selection and data recording focusing on metabolic diseases has received less attention, but is nevertheless an important issue for 
breeding goals today and in the future (Boichard and Brochard, 2012).

Metabolic disorders are disturbances to one or more of the metabolic processes. Metabolic processes are the release and conversion of metabolites that are either used in production processes or excreted as waste (Ametaj et al., 2010). Dysfunction, or physiological imbalance, of any of these processes are associated with the manifestation of metabolic diseases or disorders (Ingvartsen and Friggens, 2005). In a veterinary context, the terms diseases and disorders can be used interchangeably. In total, 72 metabolic conditions (mostly causal, some descriptive diagnoses) have been considered in the central health key included in the recommendations for recording health disorders in dairy cattle of the International Committee for Animal Recording (ICAR; http://www.icar.org/index.php/publications-technicalmaterials/recording-guidelines/, Section 7, appendix). As the occurrence of many of these diseases is likely to be too low for genetic parameter estimation, the focus of this review will be on the most prevalent diseases, in clinical or subclinical form, in addition to those for which potential indicator traits have already been reported: (1) ketosis, (2) displaced abomasum, (3) milk fever, and (4) tetany.

There are multiple and complex associations between metabolic diseases and other diseases, affecting, for example, feet and legs and reproductive function (Curtis et al., 1985). Intermediate traits, such as energy balance, could be defined to capture such relationships (e.g., Suthar et al., 2013). However, secondary conditions and feeding and management interventions will not be included in this review. Our focus is on data recording and subsequent use of these data for genetic parameter estimation and genetic evaluation.

Intense selection for production has led to a reliance on body reserves to support early lactation. Consequently, the commencement of lactation and some of the remainder of lactation are often in negative energy balance. This leads to an imbalance in hormones and metabolites giving rise to metabolic diseases (White, 2015). Dysfunction or imbalance in metabolic processes leads to disease, so it is not surprising that genetic correlations between many dairy cow production diseases and milk production traits are mostly unfavorable (e.g., Uribe et al., 1995; Pryce et al., 1997; Van Dorp et al., 1998; Zwald et al., 2004b; Koeck et al., 2013). Usable genetic variation in metabolic stability implies that breeding should be considered as a way to achieve improvements.

In 1988, the first major review of data recording opportunities and consequently breeding strategies to improve production diseases was published (Emanuelson,
1988). Since then, several countries have implemented routine genetic evaluations for health traits using predominantly producer-recorded data (Egger-Danner et al., 2015). Disease resistance breeding values are also available commercially from several breeding companies and commercial genotyping service providers. Additionally, a large amount of effort has gone into genetic analysis of subclinical disease, measured either in blood, which is often the gold standard for diagnosis of subclinical diseases, or alternatively, using other predictors from automated systems (e.g., based on routine milk analysis, on-farm sensors, or both). This is especially valuable if the predictor can be measured objectively and in a repeated manner, as it reduces the risk of bias and generally means that the genetic variation is easier to disentangle from residual variation. Furthermore, genomic selection has become a powerful enabling tool for generating breeding values where the data are only collected in a relatively small population of genotyped individuals, but the prediction equations are available for entire genotyped populations (Egger-Danner et al., 2015). Therefore, several new strategies could be used for the genetic improvement of metabolic diseases.

The aims of this review were to describe (1) largescale (national) data recording for metabolic diseases; (2) incidences of metabolic diseases from large (national) data sets; (3) issues associated with the quality of data recording; (4) heritability estimates of metabolic diseases; (5) genetic correlations with other traits; (6) overview of genetic evaluations for metabolic diseases (by country of selected countries); and (7) alternative measures and assays that can be used as predictors of metabolic diseases.

\section{NATIONAL DATA RECORDING OF DIRECT METABOLIC DISEASE TRAITS}

Consistent standards for the definition of metabolic diseases are a prerequisite in any program designed to quantify and monitor incidences, develop management practices, and estimate breeding values (Kelton et al., 1998). The first necessity is defining the disease and the basis of its clinical and subclinical diagnosis (Table 1), and second, provided the disease is measured consistently, assessing the frequency of the disease. This can either be the incidence (rate of new cases per unit of time), or prevalence, which is the proportion of animals affected at a single point in time (ICAR, 2014).

Recording programs differ between countries, due to many factors such as the reporting requirements of the country (e.g., drug usage audits) and the detail of recording in farm (herd management) software programs. 
The health data collected may also be collected by a variety of people including veterinarians, producers, para-professionals (e.g., hoof trimmer, nutritionist), or others.

In the Nordic countries, recording of health event in connecting with treatments by veterinarians have been routine since the 1970s (Heringstad and Østerås, 2013), and several direct health traits have since then been included in their routine genetic evaluations. In 2006, Austria began to develop a large-scale monitoring system based on veterinary diagnoses of health events (Schwarzenbacher et al., 2010; Egger-Danner et al., 2012a). Since the 2000s, France has instructed all livestock farmers to maintain an up-to-date farm register including animal health related interventions, which has enabled incorporating clinical mastitis into routine French genetic evaluations in 2010 (Govignon-Gio et al., 2012). A similar, mandatory farm register, including animal-health-related interventions for livestock farmers, will start in Belgium in 2016. In the southern part of Belgium, this will be co-organized by the regional breeding association, which will facilitate incorporation of novel traits into future genetic evaluations. In 2011, the United Kingdom began to develop a centralized recording system for cattle health and welfare, but data from this system have yet to be incorporated into routine evaluations despite extensive data capture on some farms. In Canada since 2007, producers record 8 diseases voluntarily (Canadian Dairy Network, 2007) and mastitis resistance has been included in genetic evaluations since 2014 (Jamrozik et al., 2013). Australia and the United States are in the research and development process of utilizing producer-recorded health data for genetic evaluations. The heterogeneity of data recording across countries and even farms is likely to affect the incidence reported by each country.

For countries that do not have established health recording systems, the best practice recommendations for data collection and trait definition, as well as the use of health data for genetic evaluations, are provided by ICAR (2014). The ICAR recording guidelines outline a comprehensive key of diagnoses with approximately 1,000 input options. The hierarchical structure allows a demand-driven subset of the diagnosis codes to be used, for example, with producer-recorded data or for paraprofessional and expert groups (e.g., hoof trimmers, nutritionists). Diseases can also be classified based on whether they occur once in an animal's lifetime, once per lactation, or repeatedly throughout an animal's lifetime. Documentation of metabolic disorders can be performed with varied levels of detail, while harmonization and standardization ensure suitability of data for joint analyses.

\section{CHARACTERISTICS AND INCIDENCES OF METABOLIC DISEASES}

Many papers have been published on disease incidences, including several reviews. For example, the study of Kelton et al. (1998) reviewed over 300 papers published from 1970 to 1996. In summary, the median incidences (per cow and year) of metabolic diseases reported in their study were $6.5 \%$ for milk fever, $8.6 \%$ for retained placenta, $10.1 \%$ for metritis, $4.8 \%$ for ketosis, and $1.7 \%$ for left displaced abomasum. However, large ranges in the incidences were reported.

For the current review, incidences were calculated from papers that studied metabolic diseases and were published between 1996 and 2015 (i.e., since the study of Kelton et al., 1998). The criteria for selecting these papers were that the incidences reported were from analyses that included at least 50 herds and 500 cows. These criteria were most likely fulfilled by surveys of national incidences and papers that included genetic parameter estimates.

\section{Ketosis}

Clinical cases of ketosis are diagnosed using findings indicative of the disease (Table 1), such as sweet-smelling breath (caused by exhalation of ketone bodies), and may also result in reduced appetite and depression of intake, reduced milk yield, changes in behavior, and in cases of prolonged energy deficit, weight loss. The costs associated with ketosis include ketosis treatment, increased risk of other diseases, risk of poorer reproductive performance, and higher risk of culling in early lactation (Gordon et al., 2013).

Both subclinical and clinical ketosis are characterized by the accumulation of ketone bodies that can be measured in blood (ketonemia), urine (ketonuria), milk (ketolactia), and other body fluids (Geishauser et al., 1998). Ketone bodies are important for energy production and are synthesized in the liver from acetyl-coA (Jorritsma et al., 1998). The major ketone bodies are BHB, acetoacetate, and acetone. Subclinical cases cannot, by definition, be observed but only diagnosed using measurements in blood, milk, lymph, and urine (Hamann and Krömker, 1997). In the literature, subclinical ketosis has been defined as when cows have at least one blood BHB test of (1) >1.2 mmol/L (Geishauser et al., 1998; Jorritsma et al., 1998; McArt et al., 2012), (2) nonesterified fatty acid (NEFA) concentration $>0.4$ $\mathrm{m} M$ prepartum, or (3) NEFA concentration $>1.0 \mathrm{~m} M$ (Raboisson et al., 2014).

Ketosis is one of the most frequent diseases in dairy cattle that is reported (Koeck et al., 2014). The num- 
Table 1. Clinical signs and indications of subclinical cases of the main metabolic diseases included in this study

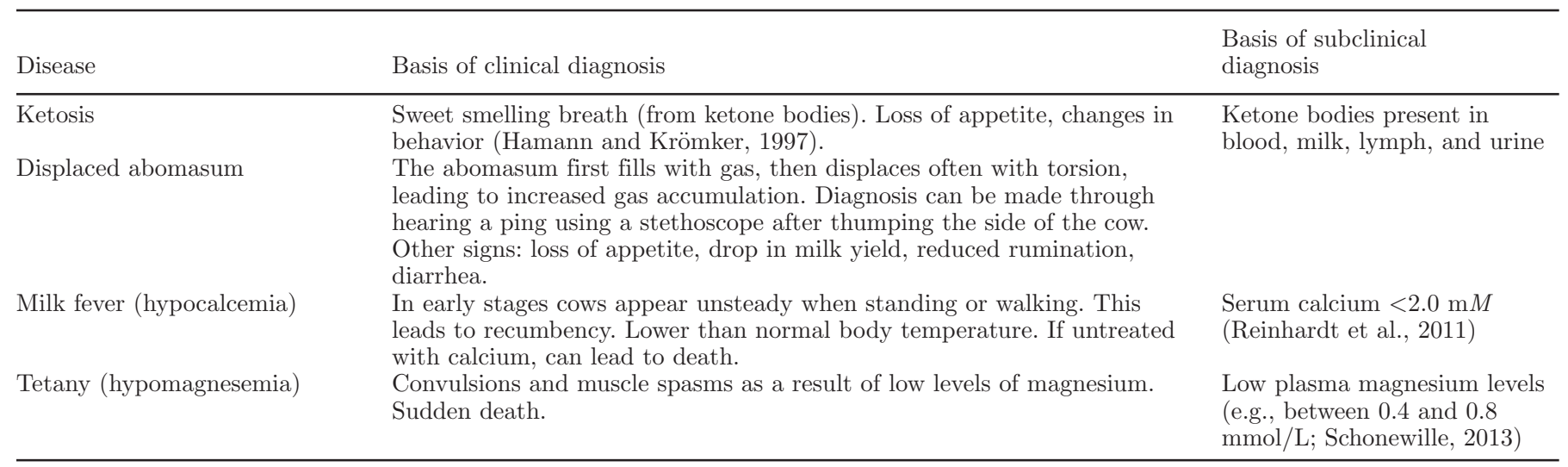

ber of large studies conducted on ketosis reflects this. Based on 18 studies that met the criteria described at the start of this section, the median incidence of ketosis was $3.3 \%$ with a range from $0.24 \%$ in first parity (Kadarmideen et al., 2000) up to $17.2 \%$ in third parity (Heringstad et al., 2005; Figure 1). These studies were conducted in many countries including Canada (Neuenschwander et al., 2012; Koeck et al., 2013), Nordic countries (Rajala-Schultz et al., 1999; Heringstad et al., 2005; Østerås et al., 2007; Espetvedt et al., 2012), Western and Central Europe (Egger-Danner et al., 2012a; Berge and Vertenten, 2014), and the United States (Zwald et al., 2004a; Cole et al., 2006; Appuhamy et al., 2009; Parker Gaddis et al., 2012; Richert et al., 2013). The median incidence calculated here (3.3\%) is lower than the median incidence of $4.8 \%$ reported by Kelton et al. (1998). This could be because the criteria used to select studies differed (ours deliberately focused on studies that were likely to be national studies, i.e., large numbers of herds).

By breed, the median incidence of ketosis from studies primarily using Holstein was $3.15 \%$ based on 11 studies across several countries. In comparison, only 2 studies met the selection criteria we applied using Norwegian Red cattle. Here the median incidence rate was $10.25 \%$. The higher incidence is likely to be linked to the recording programs in place in Norway (higher proportion of documented subclinical cases), rather than indicating truly higher incidences of clinical disease. One study each (Rajala-Schultz et al., 1999; Egger-Danner et al., 2012a) was available for Ayrshire and Fleckvieh breeds with ketosis incidences of 3.3 and $0.61 \%$, respectively. The observed differences between breeds may be partly due to differences in the number of studies available, with differences in study populations (e.g., use of first lactation only vs. inclusion of older cows), trait definitions (e.g., diagnostics, time periods included), completeness of recording, and so on. In several studies involving multiple breeds, no significant differences between the breeds were found (e.g., Fourichon et al., 2001; Richert et al., 2013; Berge and Vertenten, 2014).

It is likely that most of the incidence reports above estimated the incidence of clinical cases of ketosis, and information on subclinical cases was mostly missing. Subclinical ketosis has been reported to occur much more frequently than clinical ketosis, but is obviously more difficult to detect. Ingvartsen (2006) has reported an incidence of subclinical ketosis up to $34 \%$. Suthar et al. (2013) reported the prevalence of subclinical ketosis to be equal to $21.8 \%$, with considerable variation between 10 different countries (range from $11.2 \%$ in Turkey and up to $36.6 \%$ in Italy).

\section{Displaced Abomasum}

Displaced abomasum is a metabolic disease that often arises peripartum because of stretching of the abomasal attachments during pregnancy and the increased space in the abdominal cavity after calving. Displacement to the left occurs more commonly than displacement to the right, so most figures referring to displaced abomasum are most likely to be for left displaced abomasum. Increased filling with gas that comes along with the displacement allows diagnosis by auscultation: a typical ping is heard using a stethoscope after thumping the side of the cow. Displaced abomasum is considered to have higher data quality due to the unambiguous diagnosis and the need for timely veterinary intervention (Zwald et al., 2004a). Displaced abomasum is phenotypically associated with reduced appetite, and in the long term decreased BW, poor reproductive performance, and increased culling (Raizman and Santos, 2002). A depletion in vitamin $\mathrm{E}$ often precedes clinical diagnosis (Hasanpour et al., 2011; Qu et al., 2013). 


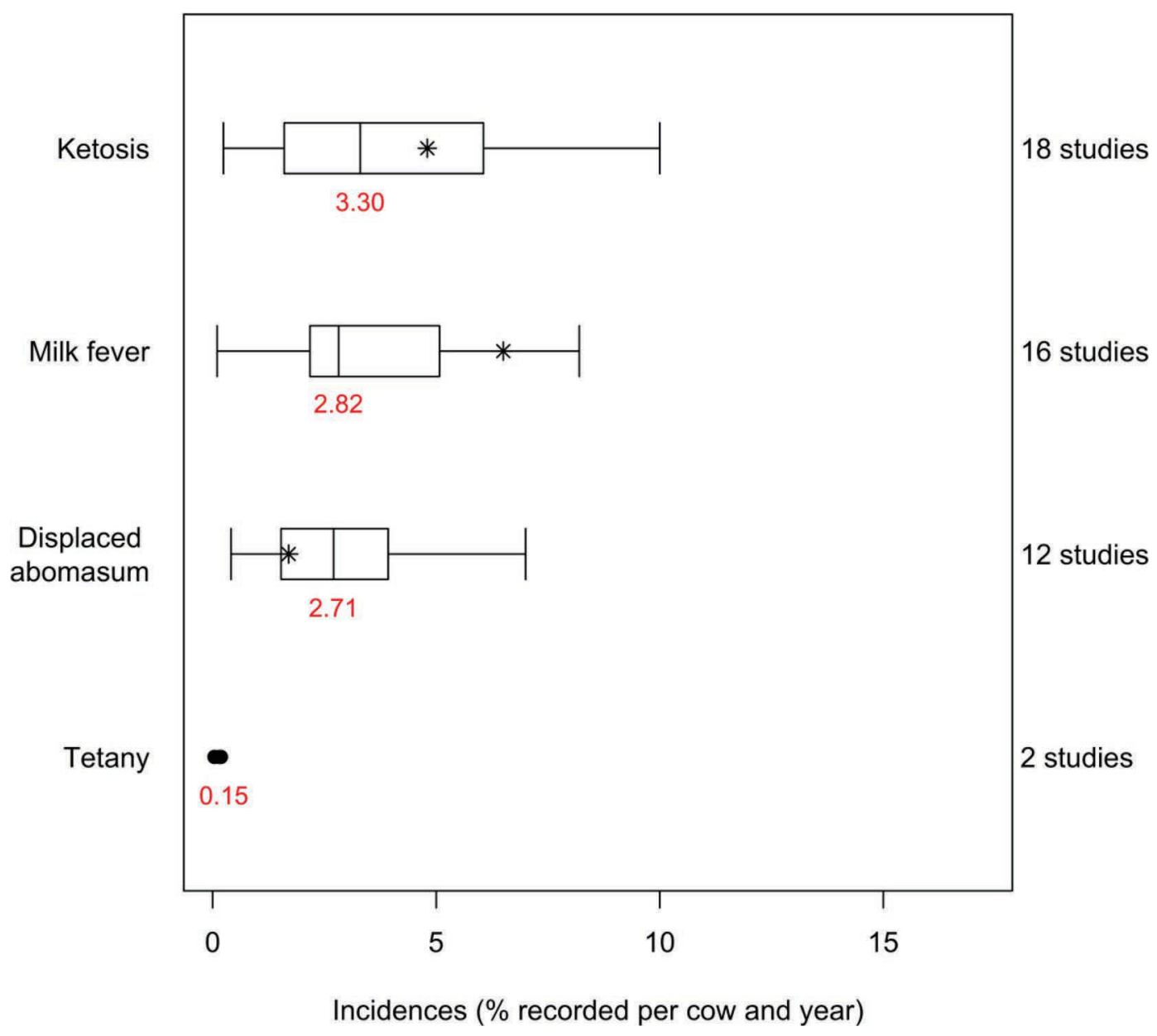

Figure 1. Reported incidences as percent per cow per year; median shown as vertical line and interquartile range as box, and range as whiskers of the following metabolic diseases: ketosis, displaced abomasum, milk fever, and tetany. Median incidence reported by Kelton et al. (1998) indicated using an asterisk. Note, only 2 studies were available for tetany, shown as black dots. Color version available online.

Incidence reports from 12 large studies were used to calculate a median reported incidence of approximately $2.71 \%$. This is higher than the incidence reported by Kelton et al. (1998). Studies were conducted in many different countries including Canada (Neuenschwander et al., 2012; Koeck et al., 2013), Western Europe (Fourichon et al., 2001; Wolf, 2001; Hamann et al., 2004), Scandinavia (Ingvartsen, 2006), and the United States (Cameron et al., 1998; Zwald et al., 2004a; Cole et al., 2006; Appuhamy et al., 2009; Parker Gaddis et al., 2012). All of these studies either used solely Holstein, or primarily Holstein, cattle. This may reflect the prominence of displaced abomasum among highproducing cows, especially Holsteins (Van Winden and Kuiper, 2003). The incidence of displaced abomasum in Norway, reported by Østerås et al. (2007), was below $0.28 \%$; note that this figure also included colic and gastrointestinal disorders.

\section{Milk Fever or Hypocalcemia}

Milk fever or hypocalcemia arises when homeostatic mechanisms fail to maintain normal blood calcium concentrations (Chamberlin et al., 2013). Milk fever is characterized by partial to complete paralysis, or "downer cows," typically occurring close to calving. It is therefore also termed "parturient paresis." Subclinical milk fever is diagnosed by decreased serum calcium $(<2.0 \mathrm{mM}$; Reinhardt et al., 2011). Although milk fever is considered easily treatable, it is a risk factor for other peripartum diseases and increased culling (Reinhardt et al., 2011). Furthermore, some cases do not respond to treatment. Older cows and over-conditioned cows have been found to be at greater risk for experiencing milk fever (DeGaris and Lean, 2008), whereas primiparous cows are much less likely to have low blood calcium levels near calving (Oetzel, 2004). 
The average incidence of milk fever was calculated from 16 studies conducted throughout North American and Europe. The median incidence of milk fever was $2.82 \%$, which is lower than the average incidence of $6.5 \%$ reported by Kelton et al. (1998). Again, this is likely to be because we focused on larger (mainly national) studies, and in field studies, it is often difficult to ensure that the diagnoses of fatal cases are completely reported. By breed, 9 studies that used primarily Holstein cattle had a median incidence of $2.9 \%$. It is difficult to tell whether there is variation in incidence between breeds, as the studies tend to be confounded by country. For example, 2 studies of Norwegian Red dairy cattle reported a median incidence of $4.5 \%$, whereas a study using Finnish Ayrshire cattle had a reported incidence of $5.7 \%$ (Rajala-Schultz et al., 1999). Two studies using primarily Fleckvieh cattle resulted in a median reported incidence of $2.73 \%$ (Frei et al., 1997; Egger-Danner et al., 2012a). Milk fever is more common among older cows, so reported incidences depend on whether all cows were included, or if only the first lactation(s) were used. When compared with clinical milk fever, the incidence of subclinical milk fever is estimated to be much higher, and associated costs may be higher as well (Oetzel, 2004). Despite being at low risk for clinical milk fever, prevalence of subclinical milk fever was estimated to be $25 \%$ in first lactation cows. Throughout later lactations, prevalence of subclinical milk fever was as high as $54 \%$ in fifth lactation cows (Reinhardt et al., 2011).

\section{Tetany}

Tetany, or hypomagnesemia, occurs when animals have insufficient amounts of magnesium utilizable for maintaining regular muscle function. It is a known risk factor for milk fever as magnesium levels are closely tied to the cow's ability to maintain calcium homeostasis (Goff, 2008). Clinical signs of tetany include changes in behavior, muscle spasms, convulsions, and paralysis (Table 1). Østerås et al. (2007) estimated the mean cow rate of tetany from 1989 through 2005 in Norwegian dairy cattle to be $0.19 \%$, whereas in UK Holsteins the mean incidence was $0.04 \%$ (Kadarmideen et al., 2000). The overall mean cow rate of tetany between these years was $0.19 \%$, with the rates being 0.18 and $0.15 \%$ in the 5 -yr spans of 2000 and 2005, respectively.

\section{Other Metabolic Diseases}

Numerous other metabolic diseases can affect dairy cattle, such as fatty liver syndrome (as results of prolonged energy deficit), anemia (iron deficiency), and other mineral and vitamin deficiencies. Few largescale studies have calculated the incidence of these other metabolic diseases. There could be a multitude of reasons for this, including very low incidence rates and difficulty of assessing and recording. For example, the main method of diagnosis for fatty liver is by liver biopsy or laparoscopy, making collection of incidence data difficult (Bobe et al., 2004).

Some studies have estimated the incidence of metabolic diseases grouped into a single trait. In a study conducted in Scandinavia, hypomagnesemia, displaced abomasum, and any other diagnoses in the national system considered to be metabolic were grouped together. The incidence rate of these events was estimated to be $1.7 \%$ in Denmark and Finland, $1.2 \%$ in Norway, and $1.5 \%$ in Sweden (Espetvedt et al., 2012).

\section{ADEQUACY OF PHENOTYPIC DATA RECORDING: UNDER-REPORTING ISSUE}

Although the interest in reliable health data recording has increased, many farm (herd management) computer systems still do not ensure that data capture for health traits is consistent and accurate. Therefore, it seems plausible that the incidence of some diseases is heavily dependent on the systems used and may on the large scale be underestimated, while others may be over-reported. On an individual basis, if the producer does not find an easy way to record data electronically, (s)he will not do it, or only do so sporadically. If reporting of antibiotic and other veterinary medical treatment is mandatory and required for farm audits, it is likely that severe cases of disease that have been treated are recorded. However, for the most severe and fatal cases, incomplete diagnosis information may be an issue that could be addressed by additional consideration of (usually less specifically recorded) culling reasons.

Under-reporting by producers may reflect a multitude of other influences including, but not limited to, current workload on the farm or differences in producer interpretation of symptoms (ICAR, 2014). It becomes a challenge to differentiate between herds that underreport a specific disease versus herds that truly have very low incidence rates of a disease (Egger-Danner et al., 2012a). Data validation studies conducted on health data have revealed indications of some degree of under-reporting (Parker Gaddis et al., 2012; Miglior et al., 2013). Other studies have shown that underreporting may make it difficult to calculate meaningful differences between countries in disease occurrence. For example, Espetvedt et al. (2012) compared the national databases of the 4 Nordic countries (Denmark, Finland, Norway, and Sweden) to farmer-observed completeness 
and veterinary-observed completeness for milk fever and ketosis. For milk fever the farmer completeness ranged between 67 and $79 \%$ and for veterinary completeness the range was between 71 and $88 \%$, with similar results for ketosis. A recent survey of 468 farm data sets in the United Kingdom, accumulated from herds believed to be good data recorders by their veterinarians, suggested that only a very small proportion (in the region of $2 \%$ ) adequately recorded metabolic diseases such as milk fever (Hudson, 2015).

For metabolic events specifically, many are subclinical by nature and as such likely undetected to large proportions. It was postulated that these diseases require, or at least receive less veterinary intervention, thus leading to underestimation of the incidence and prevalence in systems relying on veterinary data (Schwarzenbacher et al., 2010). Despite concerns of under-recording, most calculated incidences from large field studies are similar to those from well-designed epidemiological studies (e.g., Parker Gaddis et al., 2012). Furthermore, variation in recording practices across regions, herds, and also over time (e.g., in connection with personnel changes) may interfere with the suitability of fieldrecorded health data as the basis of large-scale routine monitoring systems (Østeras et al., 2007).

Under-reporting is contentious, especially when the aim of the study is to accurately estimate the incidence of disease, but is difficult to avoid when recording requires extra effort, which is likely to be case for almost all dairy farms. In this study, we deliberately focused on large studies, many of which were national. This is likely to be the main reason why the reported incidences of metabolic diseases were mostly lower than in the study of Kelton et al. (1998). From an animal breeding perspective, although it is preferable to have complete data sets of disease incidences, even data sets where only disease that was treated with drugs are recorded are still usable, as it would mean that breeding values would enable selection against severe cases of disease. Miglior et al. (2013) examined the effect of 5 different data validation methods applied to mastitis data in the Canadian health recording system. They found that the number of usable herds and number of records increased with less stringent data validation, but the frequency and heritability of mastitis decreased. Nonetheless, Pearson correlations greater than 0.95 were found between sire breeding values calculated with data from the different validation scenarios (Miglior et al., 2013).

Ultimately, completeness of data may depend on the reason for its collection, whether it be for management, epidemiological research, welfare assessment, or genetic improvement (Espetvedt et al., 2012). It is important to minimize the risk of reporting bias and systematic lack of disease information to provide unbiased predictions of the genetic liability to disease.

\section{HERITABILITY ESTIMATES OF CLINICAL CASES OF METABOLIC DISEASES}

Heritability estimates for clinical cases of ketosis, displaced abomasum, milk fever, and tetany are generally low (Table 2). Heritabilities based on linear models ranged from 0.01 to 0.39 for ketosis, 0.00 to 0.08 for displaced abomasum, 0.01 to 0.08 for milk fever, and 0.004 for tetany (Table 2). Based on threshold methodology, respective heritability estimates were 0.02 to $0.16,0.12$ to $0.35,0.07$ to 0.18 , and 0.02 . For displaced abomasum, estimates were mainly from Holstein cows, as Holsteins are considered more susceptible to displaced abomasum than other breeds (Doll et al., 2009). Recently, Ederer (2014) reported a heritability of near zero for displaced abomasum in Austrian Fleckvieh cows, which was expected, given the low frequency of the disease $(0.02 \%)$ in this breed.

Heritability estimates of farmer observed data were comparable to estimates based on veterinarian treatments (Table 2). For other metabolic diseases, such as fatty liver, no heritability estimates were available in the literature. Even though heritability estimates of metabolic diseases are low, evidence still shows that selection to improve low heritability traits can be effective. For example, the incidence of milk fever of the top and bottom 10 bulls in Canada for milk fever and ketosis breeding values differ in actual daughter incidence by $11 \%$ (Figure 2) and $16.5 \%$, respectively. For Austria, the difference between the top and bottom 10 bulls for daughter incidence of milk fever was around $10 \%$ (Figure 2).

\section{GENETIC CORRELATIONS WITH OTHER TRAITS}

\section{Milk Production Traits}

Studies on genetic correlations between metabolic diseases and milk production traits are scarce, but several older studies have reported these correlations. Genetic correlations between yield traits and ketosis, milk fever and displaced abomasum (Figure 3) varied between studies and ranged from -0.49 to 0.65 using linear models and -0.67 to 0.77 using threshold models. Only a few studies (Thompson, 1984; Tveit et al., 1991; Pryce et al., 1997; Kadarmideen et al., 2000) provided standard errors for their estimates, which ranged from 0.06 to 0.20 . For protein and fat yield, only 2 and 3 studies, respectively, had figures for each of the metabolic diseases displaced abomasum, ketosis, and milk fever. The limited number of studies, large standard 


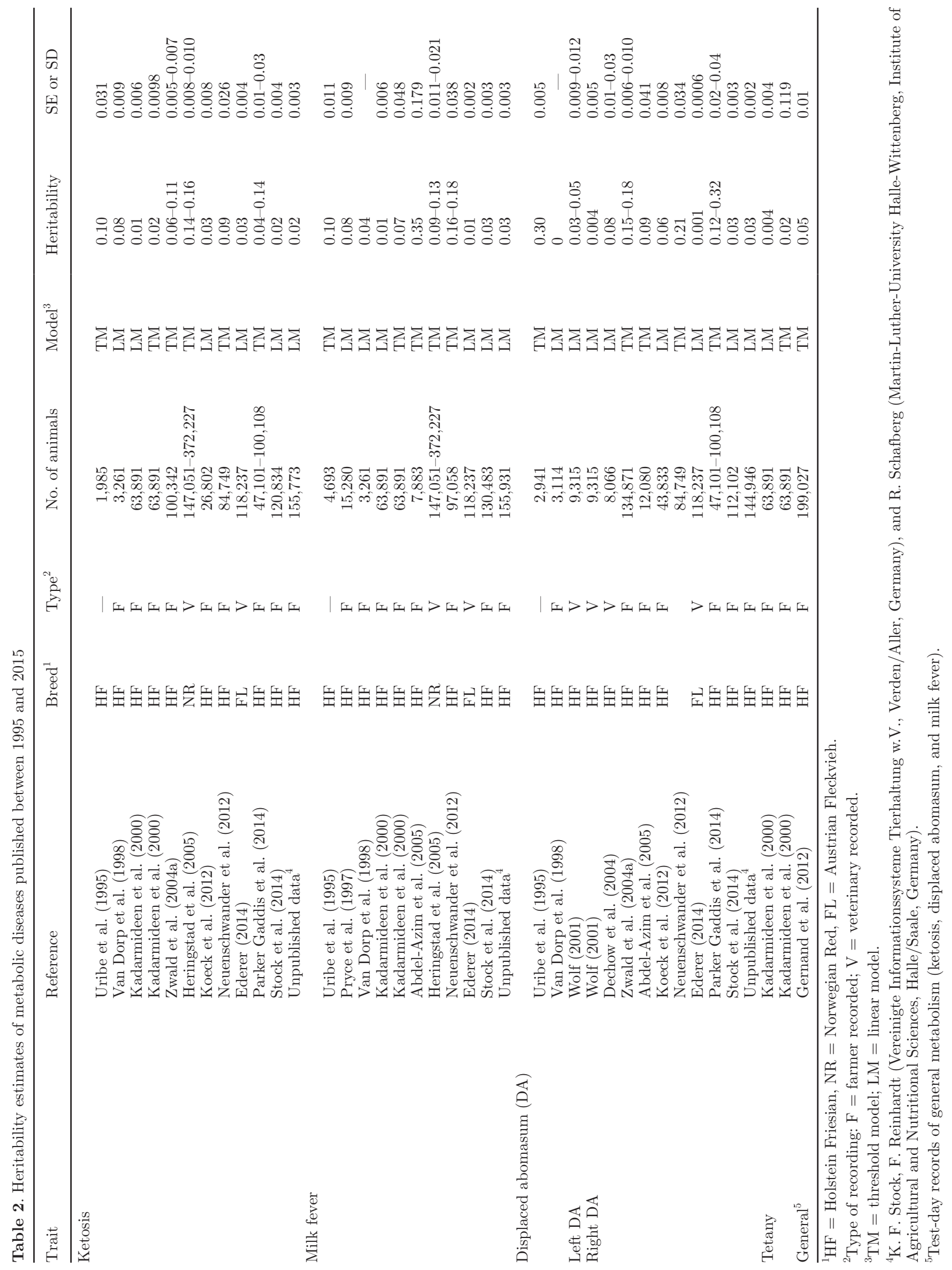




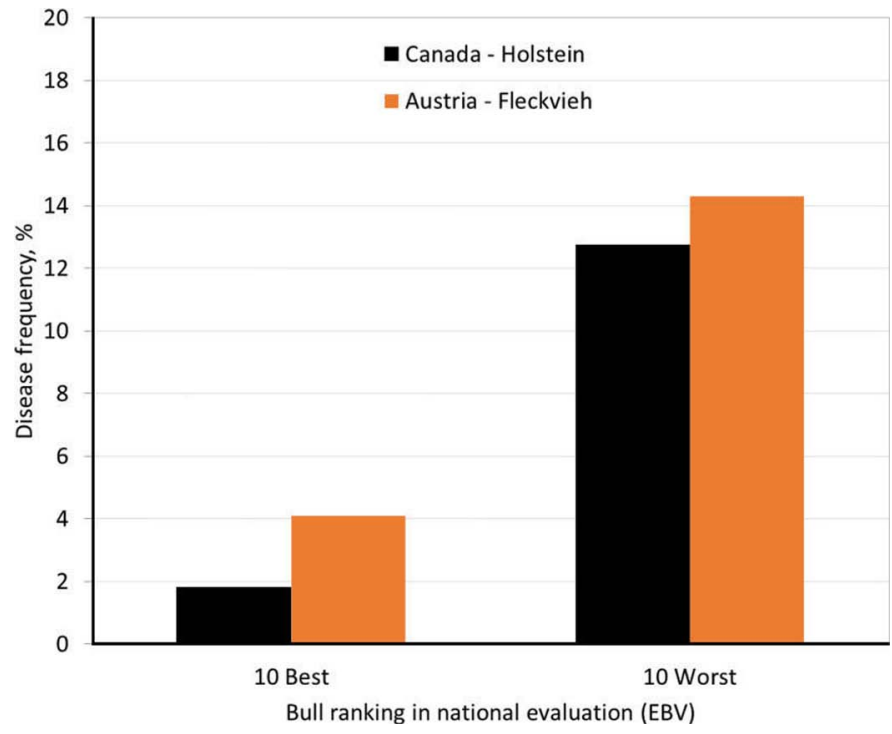

Figure 2. Clinical disease incidences of milk fever in the top 10 and bottom 10 bulls for national genetic evaluations for milk fever in Austria (Fleckvieh) and Canada (Holsteins). Color version available online. errors, and large ranges of correlation estimates make it difficult to draw general conclusions regarding the relationship between fat and protein yield and metabolic disease traits.

For genetic correlations of metabolic diseases with milk yield there were a few more studies. The means of the correlation estimates were close to zero for displaced abomasum and unfavorable for ketosis and milk fever (with large confidence intervals). Two of the studies reported very high unfavorable genetic correlations between milk yield and ketosis of 0.65 for Norwegian Red (Simianer et al., 1991) and 0.77 for Holstein Friesians (Uribe et al., 1995). In the same study, a strongly negative genetic correlation between milk fever and milk yield (-0.67) was reported (Uribe et al., 1995).

In the literature assessed, there is a lack of consistency in genetic correlation estimates between metabolic diseases and yield. One of the issues could be data set size, and therefore the correlations could be subject to sampling errors. Another issue is that some of the diseases have very low frequency. Consequently, there

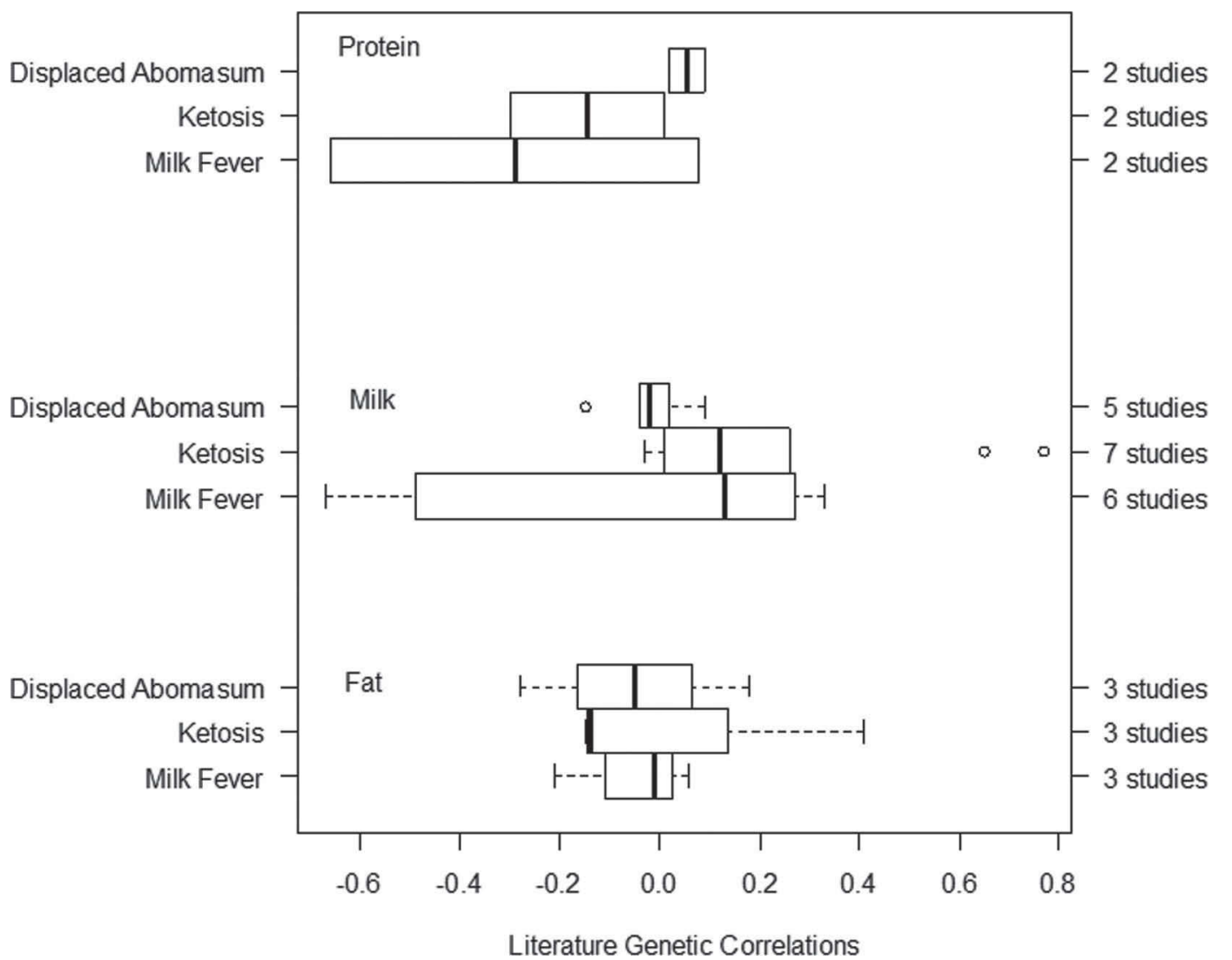

Figure 3. Genetic correlation estimate medians (vertical line), interquartile range (box), and range (whiskers) of genetic correlations with milk, fat, and protein yields of the following metabolic diseases: displaced abomasum, milk fever, and ketosis. Source: Tveit et al. (1991), Uribe et al. (1995), Pryce et al. (1997), Kadarmideen et al. (2000), Zwald et al. (2004b), Koeck et al. (2013), Parker Gaddis et al. (2014). 
is a need to estimate these correlations in much larger data sets to understand the consequences of selection practices that focus, or place a heavier weight, on milk production traits.

An alternative to estimating population level genetic correlations is to use data from selection line experiments where detailed metabolite and hormone levels have been measured. The advantage of this strategy is that pathways underpinning the effect of selection can be elucidated. For example, in their comprehensive review of selection experiments, Veerkamp et al. (2003) concluded that selection for yield has changed energy partitioning rules due to effects on the GH/IGF1 axis, confirmed by the observation that NEFA and BHB concentrations and growth hormone secretion are all generally higher in high genetic merit cows, whereas glucose levels tend to be lower.

\section{Genetic Correlations of Metabolic Diseases with Other Diseases}

Genetic correlations of metabolic diseases with other diseases were mostly positive (Table 3 ). The strongest genetic correlations were found between ketosis and displaced abomasum, with estimates ranging from 0.45 to 0.66 , so selection to improve one of these traits will lead to favorable correlated responses in the other trait. Genetic correlations between the other traits ranged from -0.21 to 0.64 .

Results from a selection experiment with Norwegian Red cows confirm that correlations between diseases are generally positive (Heringstad et al., 2007). The authors showed that selection against mastitis leads to favorable correlated selection responses in other diseases, such as ketosis and retained placenta (Heringstad et al., 2007), thus indicating the existence of a general robustness or reduced liability to disease. Furthermore, in a study by De La Paz (2008), it was found that cows with both high antibody and cell-mediated immune response have a decreased risk of disease occurrence for several diseases, including mastitis, ketosis, metritis, and retained placenta, compared with cows identified as low responders.

\section{GENETIC AND GENOMIC EVALUATIONS AND PREDICTION}

\section{Genetic Evaluations}

Some countries already estimate and publish breeding values for metabolic disease traits (Table 4), and current research efforts make it likely that more genetic evaluations for metabolic health traits will become available in the (near) future. Of the countries that already

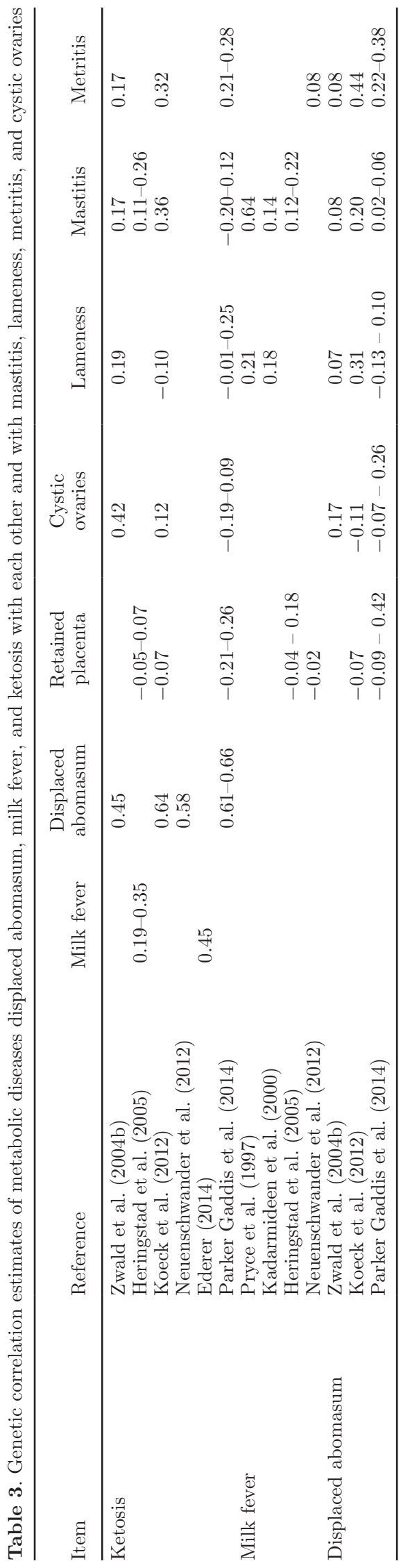


Table 4. Status of genetic evaluations for metabolic diseases from selected countries ${ }^{1}$

\begin{tabular}{|c|c|c|c|c|}
\hline Country & Ketosis & $\begin{array}{l}\text { Milk } \\
\text { fever }\end{array}$ & $\begin{array}{l}\text { Left displaced } \\
\text { abomasum }\end{array}$ & Tetany \\
\hline Australia & $\mathrm{R} \& \mathrm{D}$ & $R \& D$ & $R \& D$ & $\mathrm{R} \& \mathrm{D}$ \\
\hline Austria (+ Germany): Fleckvieh, Brown Swiss & $\mathrm{R} \& \mathrm{D}$ & Eval & & \\
\hline Belgium (Walloon region) & $\mathrm{R} \& \mathrm{D}$ & & & \\
\hline Canada & Pre & $R \& D$ & Pre & - \\
\hline Germany (+ Austria): Holstein & Pre & Pre & Pre & - \\
\hline Norway & Eval & Eval & - & - \\
\hline United Kingdom & Res & & & \\
\hline United States & R\&D & $\mathrm{R} \& \mathrm{D}$ & R\&D & - \\
\hline
\end{tabular}

${ }^{1} \mathrm{R} \& \mathrm{D}=$ research underway; Pre $=$ preliminary evaluations (including project internal evaluations); Eval $=$ official evaluations.

have official genetic evaluations for metabolic diseases described in Table 4, only Norway includes metabolic disease traits (ketosis and milk fever) in their index of overall genetic merit, as part of the "other diseases" complex. However, Denmark, Finland, and Sweden also publish breeding values for metabolic diseases (http:// www.nordicebv.info/wp-content/uploads/2015/05/

Genetic-Evaluation-of-Other-Diseases.pdf).

The first step in genetic and genomic analysis is data preparation including plausibility checks to ensure data validity. Examples of general plausibility checks include ensuring the date of an event refers to a living animal, that the animal was registered to the farm submitting the data at the time of the event, and that a particular health event is only recorded once per animal per day (ICAR, 2014). Further consideration may be necessary to determine the time span required for 2 recordings of the same event to be considered separate incidences. Additional constraints can be implemented to ensure continual recording of diseases. Several countries with ongoing collection and evaluation of health data mandate a minimum number of diagnoses per herd and year (e.g., Denmark: 0.3 diagnoses; Austria: 0.1 first diagnoses; ICAR, 2014).

Once data have been thoroughly edited and validated, several different methods of analysis are available from which to select. From Table 2 it can be seen that most studies can be divided by use of either linear or threshold model. Due to the binary nature of most metabolic disease traits, a nonlinear threshold model is theoretically more appropriate because the assumptions of a linear model are not met by binary data (Gianola, 1982). For a threshold model, one can then select to use either a logit or probit link. Several studies using mastitis have found that linear models perform equally well and are comparable to results from threshold models (e.g., Carlén et al., 2006; Koeck et al., 2010). For genetic analysis, one must also decide how to model relationship among animals using either a sire or animal model. If using a threshold model, use of an animal model may not always be possible due to extreme category problems (Hoeschele and Tier, 1995). Reliabilities estimated using threshold models also tend to be inflated, which results in evaluations appearing to be better than reality.

Cross-sectional models designate cows as either having at least one incidence of the trait of interest or having no incidences. Multiple incidences throughout a cow's lactation are not considered, and by doing this, some information is lost. Alternatively, multiple incidences of a disease could be analyzed in ordinal, censored, or longitudinal threshold models (Chang et al., 2004, 2006; Heringstad et al., 2003, 2006). Cows that are culled during lactation can also be included in survival models that allows for censoring as opposed to being disregarded. Using mastitis data, Carlén et al. (2005) found benefits in using a survival model compared with a linear model, especially in later lactations. Using simulated mastitis data, however, little difference was found when comparing linear, threshold, and survival models (Carlén et al., 2006).

Structural-equation models (Gianola and Sorensen, 2004; Wu et al., 2010) make it possible to take a causal relationship between phenotypes into account. Recursive models have, for example, been applied to infer relationship between health and fertility in cattle (Heringstad et al., 2009) and might be relevant for analyzing metabolic diseases where occurrence of one disease may cause other disease problems.

\section{Genomic Prediction}

One of the revolutionary aspects of genomic selection is the possibility of moving from using national data to well-recorded herds that are genotyped and have more detailed phenotypes and that can be used to form genomic predictions (Boichard and Brochard, 2012; Egger-Danner et al., 2015). Dedicated genomic refer- 
ence populations of females are especially cost-effective for traits that are expensive to measure (GonzalezRecio et al., 2014; Chesnais et al., 2016). However, for cheaper phenotypes, for example, those obtained from mid-infrared analysis (MIR) data or clinical diseases, much larger data sets can be assembled using nationally recorded data (Chesnais et al., 2016). This means that phenotypes used in genomic selection could be calculated for genotyped sires based on their progenies' phenotypes. Another attractive aspect of genomic selection is that information from DNA can be used to increase the reliability calculated from progeny or parent-average information, greater gains compared with conventional breeding values are expected for genotyped bulls without daughters.

To date, limited attempts have been made to calculate genomic predictions for health disorders; countries that include genomic information in their genetic prediction of health disorders include Canada, France, and the Nordic countries. Other countries, such as the United States, are in the research phase, but have found that genomic information improves the accuracy of prediction. Using one-step methods for genomic prediction, Parker Gaddis et al. (2014) calculated that blended genomic and pedigree information for unproven sires (i.e., with no progeny) resulted in reliabilities of genomic prediction of 0.35 and 0.38 for ketosis and displaced abomasum, respectively, which was an increase of 0.17 and 0.16 compared with parent average only information. Su et al. (2012) estimated genomic reliability of Nordic Red Cattle equal to approximately 0.32 for "other diseases," which included both reproductive and metabolic diseases.

\section{Selection Responses}

An important step in evaluating the effect of metabolic health traits in breeding programs is to quantify the amount of change that is achievable through selection. Selection index theory can be used to calculate selection responses, or correlated responses, to indices that consider health traits either directly or indirectly (Hazel, 1943). This is a better way of assessing the effect of selection than percentage emphasis of traits in a selection index because the correlations between traits are taken into account properly.

Studies of responses to selection in metabolic health traits are currently quite sparse and are hampered by low reliabilities often associated with low heritability traits with sparse amounts of data available. Therefore, based on economics alone, the responses achievable are likely to be modest, so it will take a long time for large direct effects on health traits to be made through genet- ics. However, selection for longevity and other health traits should result in positive selection responses in correlated health traits that do not have breeding values calculated (i.e., they are partially correlated; Pfeiffer et al., 2015). For example, Heringstad et al. (2005) and Heringstad et al. (2007) reported favorable genetic trends for ketosis in Norwegian Red Cattle, which they concluded was likely to be a correlated response to selection for mastitis resistance.

Longevity is a complex fitness trait that includes health, fertility, conformation, and calving performance (Essl, 1998) and breeding values for this trait are widely available (e.g., they are calculated and exchanged internationally by over 20 countries; http://www.interbull.org/ib/maceev_archive; accessed December 2015). Because longevity is a summary trait, improvements in many health traits are likely to have already occurred as correlated responses to selection for current local breeding objectives as a consequence of evaluating longevity. The economic value for longevity is generally derived from the benefit of cows lasting longer in a herd (Essl, 1998), while all other traits are held constant and therefore benefits for those traits in the longevity complex are only accounted for in relation to culling. Selecting for health traits directly is likely to be optimal as all the direct benefits can be accounted for (Egger-Danner et al., 2012b); however, double-counting with longevity in the breeding objective also needs to be considered.

Finally, interest is growing in developing future selection indices to include nonmarket values that take into consideration consumer preferences (e.g., increased animal welfare) permitting the construction of optimal selection objectives (Nielsen et al., 2005), which will lead to increases in the response to selection in health traits. A further development is including farmer desires in breeding objectives (Martin-Collado et al., 2015), which provides an additional mechanism for greater responses in welfare traits than the economic drivers.

\section{ALTERNATIVE WAYS OF PREDICTING METABOLIC DISEASES}

Another way to increase the accuracy of estimated breeding values and provide a mechanism for better selection responses for metabolic diseases is to use information from correlated traits, or subclinical diagnoses. In this section we will focus on traits that are easy to record either on-farm by using sensors and milk tests, or off-farm during routine milk recording. Using data obtained from milk samples has become a popular approach, probably because it is easy and relatively cheap to obtain samples, although the assays themselves could 
be expensive. There are also over 300 constituents in milk and some changes in these could be associated with subclinical disease (Hamann and Krömker, 1997).

\section{On-Farm Predictors}

Currently there is an impetus to move toward developing tools that use advanced sensors that work in close proximity to the animals, where changes can be used to modify management and become an integral part of precision farming (Gengler et al., 2013). New management systems, such as Herd Navigator (Lattec I/S, Hillerød, Denmark), have been designed to combine data from every milking with sensor-based measurements of milk and background information on disease occurrence and calving events to aid in the detection of health, fertility, and metabolic status (Bjerre-Harpøth et al., 2012). Although Herd Navigator is among the first sophisticated management systems to combine data from multiple sources to predict disease risk (among other things), it is likely to that this area will grow in the future as fully computerized farms become more commonplace. For the geneticist, under the hypothesis that this data can be transferred to centralized databases, this will lead to a more complete set of phenotypes.

Examples of predictors of diseases obtained from sensors include milk electrical conductivity, milk color, acceleration, rumen $\mathrm{pH}$, and automated condition scoring systems. A sensor system includes the device itself and interpretation software. Rutten et al. (2013) reviewed 126 publications comparing 139 systems and compared them for the following: "(I) techniques that measure something about the cow (e.g., activity); (II) interpretations that summarize changes in the sensor data (e.g., increase in activity) to produce information about the cow's status (e.g., estrus); (III) integration of information where sensor information is supplemented with other information (e.g., economic information) to produce advice (e.g., whether to inseminate a cow or not); and (IV) the farmer makes a decision or the sensor system makes the decision autonomously (e.g., the inseminator is called)." Of the studies, $16 \%$ related to the detection of metabolic diseases. These papers examined the rumen $\mathrm{pH}$ (6 studies), percentage of milkfat (1 study), level of ketone bodies in milk (3 studies), and walking activity (2 studies). Rutten et al. (2013) concluded that the detection of metabolic diseases using sensors was poor and questioned their (current) role in early detection, as most of the studies focused on whether a correlation exists between the cow measurement and sensor output. In addition to measurements obtained from sensors, on-farm milk tests could be also useful in the diagnosis of metabolic disease, especially ketosis. A variety of semiquantitative cow-side milk ketone tests exists and some of them have been demonstrated as useful tools for use in a routine monitoring program to detect subclinical ketosis (Geishauser et al., 2000). Most of them are designed to be used at the time of milking (Geishauser et al., 1998).

Nevertheless, for diseases that are difficult to diagnose, or where many cases are subclinical, improvements in sensor detection and tools for diagnosis are likely to become important. For this reason, we have focused on ketosis and energy balance as these are all ideal candidates for sensors. While energy balance is not actually a metabolic disease, metabolic disorders often arise from a negative energy balance state. Other diseases, such as milk fever, tetany, and left displaced abomasum are relatively easy to diagnose.

There may be opportunities to use other novel indicators. One example is using rumination monitoring systems to detect disease, as early results show that these can be used to diagnose health disorders before farm personnel (Stangaferro et al., 2015a,b). The number of mean days between clinical sign of disease to the day the disease was flagged by the rumination system was $-3 \mathrm{~d}$ for displaced abomasum, $-1.6 \mathrm{~d}$ for ketosis, $-0.5 \mathrm{~d}$ for indigestion, $-0.8 \mathrm{~d}$ for metritis, and $-0.8 \mathrm{~d}$ for mastitis (Stangaferro et al., 2015a). Stangaferro et al. (2015b) also compared prepartum rumination patterns from $-7 \mathrm{~d}$ to calving that for cows that developed health disorders to those cows that did not up to 30 DIM. Rumination time was reduced in cows that suffer from metabolic and digestive diseases (displaced abomasum, ketosis, and indigestion) and metritis, but not in cows with retained placenta or mastitis. Therefore, information from rumination patterns could become important as early predictors of metabolic disease. The value of this data from a genetic selection perspective is still to be quantified.

\section{Mid-Infrared Analysis}

One of the most promising ways of evaluating subclinical disease is the MIR of milk samples. In addition to the traditional traits (i.e., fat, protein, casein, lactose and urea contents), MIR analysis of milk has been used to predict other milk characteristics such as fatty acid composition, milk protein composition, milk coagulation properties, milk acidity, mineral composition, and ketone bodies (De Marchi et al., 2014). For some of these traits such as ketone bodies, the accuracy of prediction is not high enough to use MIR predicted values as reference values. However, the accuracy is sufficient for a rough screening to distinguish cows with high or low values. Hence, MIR may be an opportunity to massively increase the number of phenotypic records available for subclinical diseases, as MIR is used in 
standard milk analysis undertaken by milk recording organizations.

\section{Indicators of Ketosis}

As subclinical ketosis occurs much more often than clinical ketosis (Ingvartsen, 2006), information on subclinical cases would also be useful for genetic evaluations. Generally, the gold standard diagnosis of ketosis is based on the concentration of BHB in blood. However, blood sampling is not easily implemented on a routine basis and might be expensive for farmers.

Several authors have explored the possibility of predicting ketosis using data collected routinely through milk recording; for example, Vanholder et al. (2015) predicted that the risk of ketosis was higher when the previous lactation was extended. Phenotypes derived directly from milk production data, such as fat-to-protein ratio and milk fatty acid profiles in predicting ketosis, are promising (van Knegsel et al., 2010); however, there may be value in phenotypes more closely associated with ketosis, such as BHB and acetone in milk.

Recent studies have investigated the value of MIR to predict ketone bodies in milk as biomarkers of ketosis for both management and genetic purposes. The potential to predict acetone and BHB contents using MIR has been tested by several authors (Hansen, 1999; Heuer et al., 2001; de Roos et al., 2007; Grelet et al., 2016). All these authors concluded that MIR predicted ketone bodies adequately and that MIR might be useful for screening purposes (healthy cows vs. cows at risk of ketosis). However, the accuracy of predictive models that include only MIR predictions of acetone and BHB appears to be insufficient to achieve an acceptable diagnosis of ketosis at the individual level (de Roos et al., 2007; van der Drift et al., 2012). In fact, it appears likely that more complex models are required to adequately model ketosis (Gengler et al., 2016). For example, van der Drift et al. (2012) presented diagnostic models for the detection of ketosis in early lactation that consist of MIR-predicted acetone and BHB contents in milk in addition to test-day information such as parity, season, and fat-to-protein ratio. Moreover, Gengler et al. (2016) suggested that the relationship between milk composition and ketosis could be nonlinear and proposed using decision trees that incorporate MIR predictions of acetone, BHB, and citrate. Finally, Grelet et al. (2016) proposed predicting the risk of ketosis directly using MIR; the authors concluded that the accuracy of predicting the risk of ketosis was $85 \%$ when assessed using circulating levels of BHB and NEFA. Currently, although MIR appears to be promising as a screening tool for ketosis, it may not be sufficiently accurate for management decisions at an individual animal level, but possibly useful at a herd level. Finally, although the results of many of the published studies are promising, most of them were based on relatively small data sets and the replication of results across multiple management and feeding systems is still required.

Most studies that have investigated genetic associations between indicators of clinical ketosis have used measurements of BHB. Based on data from Canadian Holsteins, milk BHB at the first test-day was moderately genetically correlated with clinical ketosis, with estimates ranging from 0.37 to 0.75 (Koeck et al., 2014, 2015; Jamrozik et al., 2016). It seems likely that information from different sources could be used for genetic prediction in a multi-trait evaluation setting. For example, BHB from MIR could be used as one trait and clinical cases of ketosis used as another trait. Additionally, fat-to-protein ratio and other energy balance traits could be used as additional phenotypes in a multi-trait model. It is also possible that by making genetic improvement in one trait, correlated responses (improvements) in other metabolic diseases could be achieved, although this is yet to be tested. Data from Geishauser et al. (1997) showed that aspartate transaminase activity and BHB concentration in blood might be useful as predictors of subsequent displaced abomasum diagnosis.

\section{Energy Balance}

Many of the metabolic diseases are associated with cows experiencing negative energy balance, especially in early lactation. Genetically improving energy status in early lactation may assist in reducing metabolic diseases. However, calculating energy balance is not straightforward and can only be accurately assessed using calorimeter chambers (Berry et al., 2013), although it is more generally calculated as energy input minus energy output using measurements of feed energy intake and expenditure (Banos et al., 2005; Friggens et al., 2007). Several easier predictors of energy balance have been proposed, including BCS change (Roche et al., 2009) and fat-to-protein ratio (Friggens et al., 2007).

Body condition score is a subjective measure to determine the body reserves of an animal and it decreases as body reserves are mobilized to compensate negative energy balance. However, the advent of automated weighing and promising results in semi-automating body condition scoring (Bewley et al., 2008) make the use of longitudinal records across lactation a practical novel strategy to calculate energy balance (Thorup et al., 2012). In US Holstein cows, higher BCS was genetically correlated with less disease incidence for displaced 
abomasum $\left(\mathrm{r}_{\mathrm{g}}=-0.48\right)$ and metabolic and digestive diseases $\left(\mathrm{r}_{\mathrm{g}}=-0.64\right.$; Dechow et al., 2004). Similarly, Frigo et al. (2010) found that heavier BW and less BW change were correlated with fewer cases of ketosis and metabolic diseases. Loker et al. (2012) applied random regression models to investigate genetic relationships between BCS and metabolic disease throughout lactation. The average daily genetic correlation between BCS and metabolic disease was -0.44 , and was consistent throughout the lactation.

Fat-to-protein ratio has been suggested as an appropriate indicator of energy balance (Buttchereit et al., 2011) and may subsequently be related to the metabolic status of an animal. A high fat-to-protein ratio in early lactation indicates low or negative energy balance, the combined result of elevated fat percentage and decreased protein percentage. Thus, fat-to-protein ratio is negatively correlated with energy balance in early lactation, as shown by Buttchereit et al. (2011). These authors found the highest genetic correlations between fat-to-protein ratio and energy balance in the beginning of lactation $\left(\mathrm{r}_{\mathrm{g}}=-0.62\right.$ at $\left.15 \mathrm{DIM}\right)$ and correlations decreased toward zero at the end of the data recording period at 180 DIM. Estimates of genetic correlations between fat-to-protein ratio and metabolic diseases and the data to calculate it are both scarce and consequently the errors associated with estimates are large. For example, Buttchereit et al. (2012) found a genetic correlation of $0.63 \pm 0.91$ between metabolic diseases and fat-to-protein ratio in early lactation based on data from a research farm. In Canadian Holsteins, fat-to-protein ratio at the first test-day was found to be moderately genetically correlated with clinical ketosis $\left(\mathrm{r}_{\mathrm{g}}=0.30\right)$ and displaced abomasum $\left(\mathrm{r}_{\mathrm{g}}=0.26\right)$ (Koeck et al., 2013). Recently, Ederer (2014) reported positive genetic correlations of 0.38 between fat-to-protein ratio at the first test-day and ketosis and 0.18 between fatto-protein ratio at the first test-day and milk fever.

As with metabolic disease biomarkers, evidence is growing that MIR can also be used to predict energy balance (McParland et al., 2014), which can be explained because catabolism of stored adipose reserves during BCS change results in an increase in C18 fatty acid concentration in milk (Berry et al., 2013). Already several papers clearly show that MIR can be used to predict the concentration of several fatty acids (Soyeurt et al., 2006; De Marchi et al., 2014) and might therefore mirror body condition score changes.

\section{CONCLUSIONS}

There is genetic variation in metabolic disease traits, which makes direct selection to reduce the incidence of these traits possible. Indirect selection responses may have already occurred for some countries as a consequence of including longevity and health traits in breeding objectives with enough selection pressure. Only diseases with a high incidence have been included in genetic parameter estimation studies to date because a large number of affected animals are required for accurate estimation. Furthermore, the effect of selection to improve a trait with low incidence is unlikely to be worthwhile. Genetic evaluations are already calculated for some metabolic diseases in a few countries. Based on current research activities, it is likely that breeding values will be published for many others within the next decade. There is potential to use information from other sources to increase the accuracy of prediction for example, with considerable research interest in using spectral data (MIR) to predict metabolic disease and energy balance. Predictors that are on-farm or in the laboratory may be particularly useful in characterizing subclinical cases, especially where the disease is difficult to characterize. Genetic strategies to reduce metabolic disease in general may be especially useful goals for future research.

\section{ACKNOWLEDGMENTS}

J. E. Pryce acknowledges financial support from the Australian Government (Department of Agriculture and Water Resources) Rural R\&D for Profit Programme (MIRprofit). A. Koeck was supported by the Dairy Research Cluster Initiative [Dairy Farmers of Canada (Ottawa, ON), Agriculture and Agri-Food Canada (Ottawa, ON), the Canadian Dairy Network (Guelph, ON), and Canadian Dairy Commission (Ottawa, ON)]. B. Heringstad was supported by FFL/JA project number 207792 (Norway). C. Bastin and N. Gengler were supported by the National Fund for Scientific Research (FNRS), Brussels, Belgium, through different projects and the European Commission under the Seventh Framework Program through the GplusE project, grant agreement FP7-KBBE-613689; the content of the paper reflects only the view of the authors; the community is not liable for any use that may be made of the information contained in this publication. J. B. Cole was supported by appropriated project 126531000-096-00, "Improving Genetic Predictions in Dairy Animals Using Phenotypic and Genomic Information," of the Agricultural Research Service of the USDA, and J. B. Cole and K. L. Parker Gaddis were supported by Agriculture and Food Research Initiative Competitive Grant No. 2013-68004-20365, "Improving Fertility of Dairy Cattle Using Translational Genomics." Mention of trade names or commercial products in this article is 
solely for the purpose of providing specific information and does not imply recommendation or endorsement by the USDA.

\section{REFERENCES}

Abdel-Azim, G. A., A. E. Freeman, M. E. Kehrli Jr., S. C. Kelm, J. L. Burton, A. L. Kuck, and S. Schnell. 2005. Genetic basis and risk factors for infectious and noninfectious diseases in US Holsteins. I. Estimation of genetic parameters for single diseases and general health. J. Dairy Sci. 88:1199-1207.

Ametaj, B. N., Q. Zebeli, F. Saleem, N. Psychogios, M. J. Lewis, S. M. Dunn, J. Xia, and D. S. Wishart. 2010. Metabolomics reveals unhealthy alterations in rumen metabolism with increased proportion of cereal grain in the diet of dairy cows. Metabolomics 6:583-594.

Appuhamy, J. A. D. R. N., B. G. Cassell, and J. B. Cole. 2009. Phenotypic and genetic relationships of common health disorders with milk and fat yield persistencies from producer-recorded health data and test-day yields. J. Dairy Sci. 92:1785-1795.

Banos, G., M. Coffey, and S. Brotherstone. 2005. Modeling daily energy balance of dairy cows in the first three lactations. J. Dairy Sci. 88:2226-2237.

Berge, A. C., and G. Vertenten. 2014. A field study to determine the prevalence, dairy herd management systems, and fresh cow clinical conditions associated with ketosis in western European dairy herds. J. Dairy Sci. 97:2145-2154.

Berry, D., S. McParland, C. Bastin, E. Wall, N. Gengler, and H. Soyeurt. 2013. Phenotyping of robustness and milk quality. Adv. Anim. Biosci. 4:600.

Bewley, J., A. Peacock, O. Lewis, R. Boyce, D. Roberts, M. Coffey, S. Kenyon, and M. Schutz. 2008. Potential for estimation of body condition scores in dairy cattle from digital images. J. Dairy Sci. 91:3439-3453.

Bjerre-Harpøth, V., N. C. Friggens, V. M. Thorup, T. Larsen, B. M. Damgaard, K. L. Ingvartsen, and K. M. Moyes. 2012. Metabolic and production profiles of dairy cows in response to decreased nutrient density to increase physiological imbalance at different stages of lactation. J. Dairy Sci. 95:2362-2380.

Bobe, G., J. W. Young, and D. C. Beitz. 2004. Invited review: Pathology, etiology, prevention, and treatment of fatty liver in dairy cows. J. Dairy Sci. 87:3105-3124.

Boichard, D., and M. Brochard. 2012. New phenotypes for new breeding goals in dairy cattle. Animal 6:544-550.

Buttchereit, N., E. Stamer, W. Junge, and G. Thaller. 2011. Short communication: Genetic relationships among daily energy balance, feed intake, body condition score, and fat to protein ratio of milk in dairy cows. J. Dairy Sci. 94:1586-1591.

Buttchereit, N., E. Stamer, W. Junge, and G. Thaller. 2012. Genetic parameters for energy balance, fat/protein ratio, body condition score and disease traits in German Holstein cows. J. Anim. Breed. Genet. 129:280-288.

Cameron, R. E. B., P. B. Dyk, and T. H. Herdt. 1998. Dry cow diet, management, and energy balance as risk factors for displaced abomasum in high producing dairy herds. J. Dairy Sci. 81:132-139.

Canadian Dairy Network. 2007. Is Animal Health Important to You? Accessed Dec. 2015. https://www.cdn.ca/document.php?id=124.

Carlén, E., M. del P. Schneider, and E. Strandberg. 2005. Comparison between linear models and survival analysis for genetic evaluation of clinical mastitis in dairy cattle. J. Dairy Sci. 88:797-803.

Carlén, E., U. Emanuelson, and E. Strandberg. 2006. Genetic evaluation of mastitis in dairy cattle using linear models, threshold models, and survival analysis: A simulation study. J. Dairy Sci. 89:4049-4057.

Cha, E., D. Bar, J. A. Hertl, L. W. Tauer, G. Bennett, R. N. González, Y. H. Schukken, F. L. Welcome, and Y. T. Gröhn. 2011. The cost and management of different types of clinical mastitis in dairy cows estimated by dynamic programming. J. Dairy Sci. 94:4476-4487.
Cha, E., J. A. Hertl, D. Bar, and Y. T. Gröhn. 2010. The cost of different types of lameness in dairy cows calculated by dynamic programming. Prev. Vet. Med. 97:1-8.

Chamberlin, W. G., J. R. Middleton, J. N. Spain, G. C. Johnson, M. R. Ellersieck, and P. Pithua. 2013. Subclinical hypocalcemia, plasma biochemical parameters, lipid metabolism, postpartum disease, and fertility in postparturient dairy cows. J. Dairy Sci. 96:7001-7013.

Chang, Y. M., I. M. Andersen-Ranberg, B. Heringstad, D. Gianola, and G. Klemetsdal. 2006. Bivariate analysis of number of services to conception and days open in Norwegian Red using a censored threshold-linear model. J. Dairy Sci. 89:772-778.

Chang, Y. M., D. Gianola, B. Heringstad, and G. Klemetsdal. 2004 Longitudinal analysis of clinical mastitis at different stages of lactation in Norwegian cattle. Livest. Prod. Sci. 88:251-261.

Chesnais, J. P., T. A. Cooper, G. R. Wiggans, M. Sargolzaei, J. E. Pryce, and F. Miglior. 2016. Using genomics to enhance selection of novel traits in North American dairy cattle. J. Dairy Sci. 99:2413-2427.

Cole, J. B. A. H. Sanders, and J. S. Clay. 2006. Use of producer-recorded health data in determining incidence risks and relationships between health events and culling. J. Dairy Sci. 89:10 (Abstr.).

Curtis, C. R., H. N. Erb, C. J. Sniffen, R. D. Smith, and D. S. Kronfeld. 1985. Path analysis of dry period nutrition, postpartum metabolic and reproductive disorders, and mastitis in Holstein cows. J. Dairy Sci. 68:2347-2360.

De La Paz, J. M. 2008. Using humoral and cellular response to novel antigens in periparturient dairy cows as a measure of genetic disease resistance in dairy cows. MSc Thesis. Veterinary Medicine Dept., University of Florida, Gainesville.

De Marchi, M., V. Toffanin, M. Cassandro, and M. Penasa. 2014 Invited review: Mid-infrared spectroscopy as phenotyping tool for milk traits. J. Dairy Sci. 97:1171-1186.

de Roos, A. P. W., H. J. C. M. van den Bijgaart, J. Hørlyk, and G. de Jong. 2007. Screening for subclinical ketosis in dairy cattle by Fourier transform infrared spectrometry. J. Dairy Sci. 90:1761-1766.

Dechow, C. D., G. W. Rogers, U. Sander-Nielsen, L. Kiel, T. J. Lawlor, J. S. Clay, A. E. Freeman, G. Abdel-Azim, A. Kuck, and S. Schnell. 2004. Correlations among body conditions scores from various sources, dairy form, and cow health from the United States and Denmark. J. Dairy Sci. 87:3526-3533.

DeGaris, P. J., and I. J. Lean. 2008. Milk fever in dairy cows: A review of pathophysiology and control principles. Vet. J. 176:58-69.

Doll, K., M. Sickinger, and T. Seeger. 2009. New aspects in the pathogenesis of abomasal displacement. Vet. J. 181:90-96.

Ederer, S. 2014. Beziehungen von Stoffwechselerkrankungen und Merkmalen aus der Milchleistungskontrolle in der Rasse Fleckvieh. Master thesis. Department of Sustainable Agricultural Systems, University of Natural Resources and Life Sciences, Vienna, Austria.

Egger-Danner, C., J. Cole, J. Pryce, N. Gengler, B. Heringstad, A. Bradley, and K. Stock. 2015. Invited review: Overview of new traits and phenotyping strategies in dairy cattle with a focus on functional traits. Animal 9:191-207.

Egger-Danner, C., B. Fuerst-Waltl, W. Obritzhauser, C. Fuerst, H. Schwarzenbacher, B. Grassauer, M. Mayerhofer, and A. Koeck. 2012a. Recording of direct health traits in Austria-experience report with emphasis on aspects of availability for breeding purposes. J. Dairy Sci. 95:2765-2777. http://dx.doi.org/10.3168/ jds.2011-4876.

Egger-Danner, C., A. Willam, C. Fuerst, H. Schwarzenbacher, and B. Fuerst-Waltl. 2012b. Hot topic: Effect of breeding strategies using genomic information on fitness and health. J. Dairy Sci. 95:4600-4609

Emanuelson, U. 1988. Recording of production diseases in cattle and possibilities for genetic improvements: A review. Livest. Prod. Sci. 20:89-106.

Espetvedt, M. N., C. Wolff, S. Rintakoski, A. Lind, and O. Østerås 2012. Completeness of metabolic disease recordings in Nordic national databases for dairy cows. Prev. Vet. Med. 105:25-37. 
Essl, A. 1998. Longevity in dairy cattle breeding: A review. Livest. Prod. Sci. 57:79-89.

Fourichon, C., F. Beaudeau, N. Bareille, and H. Seegers. 2001. Incidence of health disorders in dairy farming systems in western France. Livest. Prod. Sci. 68:157-170.

Frei, C., P. P. Frei, K. D. C. Stärk, D. U. Pfeiffer, and U. Kihm. 1997. The production system and disease incidence in a national random longitudinal study of Swiss dairy herds. Prev. Vet. Med. 32:1-21.

Friggens, N. C., P. Berg, P. Theilgaard, I. R. Korsgaard, K. L. Ingvartsen, P. Løvendahl, and J. Jensen. 2007. Breed and parity effects on energy balance profiles through lactation: Evidence of genetically driven body energy change. J. Dairy Sci. 90:5291-5305.

Frigo, E., C. D. Dechow, O. Pedron, and B. G. Cassell. 2010. The genetic relationship of body weight and early-lactation health disorders in two experimental herds. J. Dairy Sci. 93:1184-1192.

Geishauser, T., K. Leslie, T. Duffield, and V. Edge. 1997. Evaluation of aspartate transaminase activity and beta-hydroxybutyrate concentration in blood as tests for prediction of left displaced abomasum in dairy cows. Am. J. Vet. Res. 58:1216-1220.

Geishauser, T., K. Leslie, D. Kelton, and T. Duffield. 1998. Evaluation of five cowside tests for use with milk to detect subclinical ketosis in dairy cows. J. Dairy Sci. 81:438-443.

Geishauser, T., K. Leslie, J. Tenhag, and A. Bashiri. 2000. Evaluation of eight cow-side ketone tests in milk for detection of subclinical ketosis in dairy cows. J. Dairy Sci. 83:296-299.

Gengler, N., D. Berry, and C. Bastin. 2013. Use of automated systems for recording of direct and indirect data with special emphasis on the use of MIR milk spectra (OptiMIR project). ICAR Technical Series no. 17:55.

Gengler, N., H. Soyeurt, F. Dehareng, C. Bastin, F. G. Colinet, H. Hammami, M.-L. Vanrobays, A. Lainé, S. Vanderick, A. Vanlierde, E. Froidmont, and P. Dardenne. 2016. Capitalizing on fine milk composition for breeding and management of dairy cows. J. Dairy Sci. 99:4071-4079.

Gernand, E., P. Rehbein, U. U. von Borstel, and S. König. 2012. Incidences of and genetic parameters for mastitis, claw disorders, and common health traits recorded in dairy cattle contract herds. J. Dairy Sci. 95:2144-2156.

Gianola, D. 1982. Theory and analysis of threshold characters. J. Anim. Sci. 54:1079-1096.

Gianola, D., and D. Sorensen. 2004. Quantitative genetic models for describing simultaneous and recursive relationships between phenotypes. Genetics 167:1407-1424.

Goff, J. P. 2008. The monitoring, prevention, and treatment of milk fever and subclinical hypocalcemia in dairy cows. Vet. J. 176:50-57.

Gonzalez-Recio, O., M. P. Coffey, and J. E. Pryce. 2014. On the value of the phenotypes in the genomic era. J. Dairy Sci. 97:7905-7915.

Gordon, J. L., S. J. LeBlanc, and T. F. Duffield. 2013. Ketosis treatment in lactating dairy cattle. Vet. Clin. North Am. Food Anim. Pract. 29:433-445.

Govignon-Gio, A., R. Dassonneville, G. Balloche, and V. Ducrocq. 2012. Genetic evaluation of mastitis in dairy cattle in France. Interbull Bull. 46:121-126.

Grelet, C., C. Bastin, M. Gelé, J.-B. Davière, M. Johan, A. Werner, R. Reding, J. A. Fernandez Pierna, F. G. Colinet, P. Dardenne, N. Gengler, H. Soyeurt, and F. Dehareng. 2016. Development of Fourier transform mid-infrared calibrations to predict acetone, $\beta$-hydroxybutyrate and citrate contents in bovine milk through a European dairy network. J. Dairy Sci. 99:4816-4825.

Hamann, J., and V. Krömker. 1997. Potential of specific milk composition variables for cow health management. Livest. Prod. Sci. 48:201-208.

Hamann, H., V. Wolf, H. Scholz, and O. Distl. 2004. Relationships between lactational incidence of displaced abomasum and milk production traits in German Holstein cows. J. Vet. Med. Ser. A 51:203-208. http://dx.doi.org/10.1111/j.1439-0442.2004.00626.x.

Hansen, P. W. 1999. Screening of dairy cows for ketosis by use of infrared spectroscopy and multivariate calibration. J. Dairy Sci. $82: 2005-2010$.
Hasanpour, A., N. Saranjam, and B. A. Tabrizi. 2011. Antioxidant concentration status in the serum of cows with left displacement abomasum. Global Veterinaria 7:478-481.

Hazel, L. N. 1943. The genetic basis for constructing selection indexes. Genetics 28:476-490.

Heringstad, B., Y. M. Chang, I. M. Andersen-Ranberg, and D. Gianola. 2006. Genetic analysis of number of mastitis cases and number of services to conception using a censored threshold model. J. Dairy Sci. 89:4042-4048.

Heringstad, B., Y. M. Chang, D. Gianola, and G. Klemetsdal. 2003. Genetic analysis of longitudinal trajectory of clinical mastitis in first-lactation Norwegian cattle. J. Dairy Sci. 86:2676-2683.

Heringstad, B., Y. M. Chang, D. Gianola, and G. Klemetsdal. 2005. Genetic analysis of clinical mastitis, milk fever, ketosis, and retained placenta in three lactations of Norwegian Red cows. J. Dairy Sci. 88:3273-3281.

Heringstad, B., G. Klemetsdal, and T. Steine. 2007. Selection responses for disease resistance in two selection experiments with Norwegian Red cows. J. Dairy Sci. 90:2419-2426.

Heringstad, B., and O. Østerås. 2013. More than 30 years of health recording in Norway. In ICAR Technical Series no. 17. 39-46.

Heringstad, B., X.-L. Wu, and D. Gianola. 2009. Inferring relationships between health and fertility in Norwegian Red cows using recursive models. J. Dairy Sci. 92:1778-1784.

Heuer, C., H. J. Luinge, E. T. G. Lutz, Y. H. Schukken, J. H. van der Maas, H. Wilmink, and J. P. T. M. Noordhuizen. 2001. Determination of acetone in cow milk by Fourier transform infrared spectroscopy for the detection of subclinical ketosis. J. Dairy Sci. $84: 575-582$.

Hoeschele, I., and B. Tier. 1995. Estimation of variance components of threshold characters by marginal posterior modes and means of Gibbs sampling. Genet. Sel. Evol. 27:519-540.

Hudson, C. D. 2015. Big data and the dairy cow: Factors affecting fertility in UK herds. PhD Thesis, School of Veterinary Medicine and Science, University of Nottingham, Nottingham, UK.

ICAR. 2014. ICAR Recording Guidelines. International Agreement of Recording Practices. Berlin, Germany. http://www.icar.org/index. $\mathrm{php} /$ publications-technical-materials/recording-guidelines/.

Ingvartsen, K. L. 2006. Feeding- and management-related diseases in the transition cow. Physiological adaptations around calving and strategies to reduce feeding-related diseases. Anim. Feed Sci. Technol. 126:175-213

Ingvartsen, K. L., and N. C. Friggens. 2005. To what extent do variabilities in hormones, metabolites and energy intake explain variability in milk yield? Domest. Anim. Endocrinol. 29:294-304.

Jamrozik, J., A. Koeck, G. J. Kistemaker, and F. Miglior. 2016. Multiple-trait estimates of genetic parameters for metabolic disease traits, fertility disorders, and their predictors in Canadian Holsteins. J. Dairy Sci. 99:1990-1998.

Jamrozik, J., A. Koeck, F. Miglior, G. J. Kistemaker, F. S. Schenkel, D. F. Kelton, and B. J. Van Doormaal. 2013. Genetic and genomic evaluation of mastitis resistance in Canada. Interbull Bull. $47: 43-51$

Jorritsma, R., S. Baldee, Y. Schukken, T. Wensing, and G. Wentink. 1998. Evaluation of a milk test for detection of subclinical ketosis. Vet. Q. 20:108-110.

Kadarmideen, H. N., R. Thompson, and G. Simm. 2000. Linear and threshold model genetic parameters for disease, fertility and milk production in dairy cattle. Anim. Sci. 71:411-419.

Kelton, D. F., K. D. Lissemore, and R. E. Martin. 1998. Recommendations for recording and calculating the incidence of selected clinical diseases of dairy cattle. J. Dairy Sci. 81:2502-2509.

Koeck, A., B. Heringstad, C. Egger-Danner, C. Fuerst, and B. FuerstWaltl. 2010. Comparison of different models for genetic analysis of clinical mastitis in Austrian Fleckvieh dual-purpose cows. J. Dairy Sci. 93:4351-4358. http://dx.doi.org/10.3168/jds.2009-2955.

Koeck, A., J. Jamrozik, G. J. Kistemaker, F. S. Schenkel, R. K. Moore, D. M. Lefebvre, D. F. Kelton, and F. Miglior. 2015. Development of genetic evaluations for metabolic disease traits for Canadian dairy cattle. Interbull Bull. 49:76-79. 
Koeck, A., J. Jamrozik, F. S. Schenkel, R. K. Moore, D. M. Lefebvre, D. F. Kelton, and F. Miglior. 2014. Genetic analysis of milk $\beta$-hydroxybutyrate and its association with fat to protein ratio, body condition score, clinical ketosis and displaced abomasum in early first lactation Canadian Holsteins. J. Dairy Sci. 97:72867292 .

Koeck, A., F. Miglior, J. Jamrozik, D. F. Kelton, and F. S. Schenkel. 2013. Genetic associations of ketosis and displaced abomasum with milk production traits in early first lactation of Canadian Holsteins. J. Dairy Sci. 96:4688-4696.

Koeck, A., F. Miglior, D. F. Kelton, and F. S. Schenkel. 2012. Health recording in Canadian Holsteins: Data and genetic parameters. J. Dairy Sci. 95:4099-4108.

Loker, S., F. Miglior, A. Koeck, T. F. Neuenschwander, C. Bastin, J. Jamrozik, L. R. Schaeffer, and D. Kelton. 2012. Relationships between body condition score and health traits in first-lactation Canadian Holsteins. J. Dairy Sci. 95:6770-6780.

Martin-Collado, D., T. Byrne, P. Amer, B. Santos, M. Axford, and J. Pryce. 2015. Analyzing the heterogeneity of farmers' preferences for improvements in dairy cow traits using farmer typologies. J. Dairy Sci. 98:4148-4161.

McArt, J. A. A., D. V. Nydam, and G. R. Oetzel. 2012. Epidemiology of subclinical ketosis in early lactation dairy cattle. J. Dairy Sci. 95:5056-5066.

McParland, S., E. Lewis, E. Kennedy, S. Moore, B. McCarthy, M O'Donovan, S. Butler, J. Pryce, and D. Berry. 2014. Mid-infrared spectrometry of milk as a predictor of energy intake and efficiency in lactating dairy cows. J. Dairy Sci. 97:5863-5871.

Miglior, F., A. Koeck, D. F. Kelton, and F. S. Schenkel. 2013. Comparison of different methods to validate a dataset with producerrecorded health events. In Challenges and benefits of health data recording in the context of food chain quality, management and breeding. Proceedings of the ICAR Conference, Aarhus, Denmark, 30-31 May 2013. International Committee for Animal Recording (ICAR). 109-116.

Neuenschwander, T. F.-O., F. Miglior, J. Jamrozik, O. Berke, D. F. Kelton, and L. R. Schaeffer. 2012. Genetic parameters for producer-recorded health data in Canadian Holstein cattle. Animal 6:571-578.

Nielsen, H.-M., L. G. Christensen, and A. F. Groen. 2005. Derivation of sustainable breeding goals for dairy cattle using selection index theory. J. Dairy Sci. 88:1882-1890.

Oetzel, G. R. 2004. Monitoring and testing dairy herds for metabolic disease. Vet. Clin. North Am. Food Anim. Pract. 20:651-674.

Østerås, O., H. Solbu, A. O. Refsdal, T. Roalkvam, O. Filseth, and A. Minsaas. 2007. Results and evaluation of thirty years of health recordings in the Norwegian dairy cattle population. J. Dairy Sci. 90:4483-4497. http://dx.doi.org/10.3168/jds.2007-0030.

Parker Gaddis, K. L., J. B. Cole, J. S. Clay, and C. Maltecca. 2012. Incidence validation and relationship analysis of producer-recorded health event data from on-farm computer systems in the United States. J. Dairy Sci. 95:5422-5435.

Parker Gaddis, K. L., J. B. Cole, J. S. Clay, and C. Maltecca. 2014. Genomic selection for producer-recorded health event data in US dairy cattle. J. Dairy Sci. 97:3190-3199.

Pfeiffer, C., C. Fuerst, V. Ducrocq, and B. Fuerst-Waltl. 2015. Short communication: Genetic relationships between functional longevity and direct health traits in Austrian Fleckvieh cattle. J. Dairy Sci. 98:7380-7383.

Pryce, J. E., R. F. Veerkamp, R. Thompson, W. G. Hill, and G. Simm. 1997. Genetic aspects of common health disorders and measures of fertility in Holstein Friesian dairy cattle. Anim. Sci. 65:353-360.

Qu, Y., K. Lytle, M. G. Traber, and G. Bobe. 2013. Depleted serum vitamin $\mathrm{E}$ concentrations precede left displaced abomasum in early-lactation dairy cows. J. Dairy Sci. 96:3012-3022.

Raboisson, D., M. Mounié, and E. Maigné. 2014. Diseases, reproductive performance, and changes in milk production associated with subclinical ketosis in dairy cows: A meta-analysis and review. J. Dairy Sci. 97:7547-7563.
Raizman, E. A., and J. Santos. 2002. The effect of left displacement of abomasum corrected by toggle-pin suture on lactation, reproduction, and health of Holstein dairy cows. J. Dairy Sci. 85:1157-1164.

Rajala-Schultz, P. J., Y. T. Gröhn, and C. E. McCulloch. 1999. Effects of milk fever, ketosis, and lameness on milk yield in dairy cows. J. Dairy Sci. 82:288-294.

Reinhardt, T. A., J. D. Lippolis, B. J. McCluskey, J. P. Goff, and R. L. Horst. 2011. Prevalence of subclinical hypocalcemia in dairy herds. Vet. J. 188:122-124.

Richert, R. M., K. M. Cicconi, M. J. Gamroth, Y. H. Schukken, K. E. Stiglbauer, and P. L. Ruegg. 2013. Risk factors for clinical mastitis, ketosis, and pneumonia in dairy cattle on organic and small conventional farms in the United States. J. Dairy Sci. 96:4269-4285.

Roche, J. R., N. C. Friggens, J. K. Kay, M. W. Fisher, K. J. Stafford, and D. P. Berry. 2009. Invited review: Body condition score and its association with dairy cow productivity, health, and welfare. J. Dairy Sci. 92:5769-5801.

Rutten, C. J., A. Velthuis, W. Steeneveld, and H. Hogeveen. 2013 Invited review: Sensors to support health management on dairy farms. J. Dairy Sci. 96:1928-1952.

Schonewille, J. T. 2013. Magnesium in dairy cow nutrition: An overview. Plant Soil 368:167-178.

Schwarzenbacher, H., W. Orbitzhauser, B. Fuerst-Waltl, A. Koeck, and C. Egger-Danner. 2010. Health monitoring system in Austrian dual purpose Fleckvieh cattle: Incidences and prevalences. In Book of Abstracts of the 61th Annu. Meeting of the EAAP. Wageningen Academic Publishers, the Netherlands, Heraklion, Greece. 145.

Simianer, H., H. Solbu, and L. R. Schaeffer. 1991. Estimated genetic correlations between disease and yield traits in dairy cattle. J. Dairy Sci. 74:4358-4365.

Soyeurt, H., P. Dardenne, F. Dehareng, G. Lognay, D. Veselko, M Marlier, C. Bertozzi, P. Mayeres, and N. Gengler. 2006. Estimating fatty acid content in cow milk using mid-infrared spectrometry. J. Dairy Sci. 89:3690-3695.

Stangaferro, M. L., R. Wijma, M. M. Medrano, M. A. Al Abri, and J. O. Giordano. 2015a. Prepartum rumination patterns in dairy cows that develop health disorders in the early postpartum period. J. Dairy Sci. 98(Suppl. 2):327. (Abstr.)

Stangaferro, M. L., R. Wijma, C. E. Quinteros, M. M. Medrano, M. Masello, and J. O. Giordano. 2015b. Use of a rumination and activity monitoring for the identification of dairy cows with health disorders. J. Dairy Sci. 98(Suppl. 2):506-507. (Abstr.)

Stock, K. F., J. Wiebelitz, and F. Reinhardt. 2014. Health traits and their role for sustainability improvement of dairy production. 65th Annual Meeting of the EAAP, 25-29 August 2014, Copenhagen, Denmark. http://www.gkuh.de/DivDok/VortragEAAP2014_ HealthTraitsDairy_S20_18857.pdf.

Su, G., P. Madsen, U. S. Nielsen, E. A. Mäntysaari, G. P. Aamand, O. F. Christensen, and M. S. Lund. 2012. Genomic prediction for Nordic Red Cattle using one-step and selection index blending. J. Dairy Sci. 95:909-917.

Suthar, V. S., J. Canelas-Raposo, A. Deniz, and W. Heuwieser. 2013. Prevalence of subclinical ketosis and relationships with postpartum diseases in European dairy cows. J. Dairy Sci. 96:2925-2938.

Thompson, J. R. 1984. Genetic interrelationships of parturition problems and production. J. Dairy Sci. 67:628-635.

Thorup, V. M., D. Edwards, and N. C. Friggens. 2012. On-farm estimation of energy balance in dairy cows using only frequent body weight measurements and body condition score. J. Dairy Sci. 95:1784-1793.

Tveit, B., M. Svendsen, and K. Hove. 1991. Heritability of hypocalcemia at first parturition in Norwegian cattle: genetic correlations with yield and weight. J. Dairy Sci. 74:3561-3567.

Uribe, H. A., B. W. Kennedy, S. W. Martin, and D. F. Kelton. 1995 Genetic parameters for common health disorders of Holstein cows. J. Dairy Sci. 78:421-430.

van der Drift, S. G. A., K. J. E. van Hulzen, T. G. Teweldemedhn R. Jorritsma, M. Nielen, and H. C. M. Heuven. 2012. Genetic and nongenetic variation in plasma and milk $\beta$-hydroxybutyrate and milk acetone concentrations of early-lactation dairy cows. J. Dairy Sci. 95:6781-6787. 
Van Dorp, T. E., J. C. M. Dekkers, S. W. Martin, and J. P. T. M. Noordhuizen. 1998. Genetic parameters of health disorders, and relationships with 305-day milk yield and conformation traits of registered Holstein cows. J. Dairy Sci. 81:2264-2270.

van Knegsel, A., S. van der Drift, M. Horneman, A. de Roos, B. Kemp, and E. Graat. 2010. Short communication: Ketone body concentration in milk determined by Fourier transform infrared spectroscopy: Value for the detection of hyperketonemia in dairy cows. J. Dairy Sci. 93:3065-3069.

Van Winden, S. C. L., and R. Kuiper. 2003. Left displacement of the abomasum in dairy cattle: Recent developments in epidemiological and etiological aspects. Vet. Res. 34:47-56.

Vanholder, T., J. Papen, R. Bemers, G. Vertenten, and A. Berge. 2015. Risk factors for subclinical and clinical ketosis and association with production parameters in dairy cows in the Netherlands. J. Dairy Sci. 98:880-888.

Veerkamp, R., B. Beerda, and T. Van der Lende. 2003. Effects of genetic selection for milk yield on energy balance, levels of hormones, and metabolites in lactating cattle, and possible links to reduced fertility. Livest. Prod. Sci. 83:257-275.
White, H. M. 2015. The role of TCA cycle anaplerosis in ketosis and fatty liver in periparturient dairy cows. Animals (Basel) 5:793-802.

Wolf, V. 2001. Populationsgenetische Untersuchung zum Auftreten Labmagenverlagerung bei Deutschen Holstein Kühen. PhD thesis. University of Veterinary Medicine Hannover, Hannover, Germany.

Wu, X.-L., B. Heringstad, and D. Gianola. 2010. Bayesian structural equation models for inferring relationships between phenotypes: A review of methodology, identifiability, and applications. J. Anim. Breed. Genet. 127:3-15.

Zwald, N. R., K. A. Weigel, Y. M. Chang, R. D. Welper, and J. S. Clay. 2004a. Genetic selection for health traits using producerrecorded data. I. Incidence rates, heritability estimates, and sire breeding values. J. Dairy Sci. 87:4287-4294.

Zwald, N. R., K. A. Weigel, Y. M. Chang, R. D. Welper, and J. S. Clay. 2004b. Genetic selection for health traits using producerrecorded data. II. Genetic correlations, disease probabilities, and relationships with existing traits. J. Dairy Sci. 87:4295-4302. 